\title{
Research on the problem and countermeasures of charging stations applied in large-scale
}

\author{
Tao Jiang ${ }^{1, a}$, Liang Shen ${ }^{1}$, Fen Qin ${ }^{1}$, Tiyin $\mathrm{Li}^{2}$ and Weiyong $\mathrm{Yu}^{1}$ \\ ${ }^{1}$ Hangzhou Kaida Electric Power Construction Co., LTD, Zhejiang, 310000, China \\ ${ }^{2}$ State Grid Power Supply Company of Zhejiang Yuhang, Zhejiang, 310000 China
}

\begin{abstract}
During the "13th five-year plan period", the central government pay higher attention and energetic support to new energy vehicles. But the main factor restricts the development of new energy vehicles is charging station construction lagging behind. There is an urgent need for large-scale application of charging station problems faced by research and analysis, and proposed countermeasures. This paper in-depth analyzes the current situation of charging station, problems, influencing factors, suggestions and economic benefits, provides more scientific, reliable theoretical basis for the relevant government departments and points out the direction for a wide range of cooperation between government, business and the masses. At the same time, on the basis of theoretical research, put forward operable suggestions combined with the actual situation to improve charging stations application scope and energy saving.
\end{abstract}

Keywords: new energy vehicles; charging station; application scope; operable suggestions.

\section{Introduction}

Under the increasing global attention to the issue of energy saving, new energy vehicles came into being. With the scale of China's new energy vehicles continues to expand, the demand for charging stations are also increasing, but the number of charging stations construction is much lower than sales of new energy vehicles, the slow development of charging station construction has severely restricted the development of new energy vehicles. Based on the above situation, we investigate the problem charging stations applications are facing in China, analysis restricted charging stations unavoidable factors and countermeasures against these constraints.

\section{The main problem of the charging stations application existence}

\subsection{Charging stations narrow range of applications, lack of promotion efforts}

January to August 2015, the national new energy car sales have exceeded 110,000. China will surpass the US to become the new energy vehicle sales and ownership superpower. It can be seen, domestic new energy vehicles have entered a rapid development stage, have been gradually narrowing the gap with developed countries. In the United States, electric vehicle charging facilities distribution has been

a Corresponding author : kdjiangtao2016@126.com 
basically covered the whole country, and has achieved the parking charge integration. The Japanese government attaches great importance to the development and application charge stations[1], planned for 2020, Japan pure electric vehicle fast charging stations built in 5000 and home charging stations built in 2 million. In France, the power companies build a lot of charging stations, while the new energy vehicles can be in charge at home[2].

At present, the domestic construction of new energy vehicle charging stations is still in infancy, a small number of charging stations relatively new energy vehicles. By the end of 2014, China has accumulated production of new energy vehicles 113,000 , but only 30,914 charging stations, the ratio is about $24.7 \%$, far below the reasonable level of 1: 1 . Statistics show that between 2010 and 2014, the number of charging stations increased from 76 to 723, the annual compound growth rate of 75.6\% [3-5]. According to statistics, by the end of 2014, the State Grid completed a total of 618 filling in power stations, 24000 charging stations, including 218 new filling in power stations and 5000 charge stations.

Table 1. List of the Charging Facility in 2010-2014

\begin{tabular}{|c|c|c|c|c|}
\hline & $\mathbf{2 0 1 1}$ & $\mathbf{2 0 1 2}$ & $\mathbf{2 0 1 3}$ & $\mathbf{2 0 1 4}$ \\
\hline $\begin{array}{c}\text { Accumulative total build filling in power } \\
\text { stations (Block) }\end{array}$ & 243 & 353 & 400 & 618 \\
\hline $\begin{array}{c}\text { Accumulative total builds charging stations } \\
\text { (million units) }\end{array}$ & 1.3 & 1.47 & 1.9 & 2.4 \\
\hline $\begin{array}{c}\text { Built filling in power stations (Block) } \\
\text { Built charging stations (million units) }\end{array}$ & 156 & 110 & 47 & 218 \\
\hline
\end{tabular}

In the State Grid "12th five-year plan period intelligent network planning", it plans to construct 904 filling in power stations and 233,000 charging stations and to invest 21.71 billion yuan in charging facilities. From 2011 to 2015, the size of new energy vehicle charging station of State Grid reaches 4000; from 2016 to 2020, State Grid construction target is up to 10,000 charging stations, to build complete new energy vehicle charging network. According to the original plan from 2011 to 2015, the size reaches 4000; but up to 2015 only completed $10 \%$.

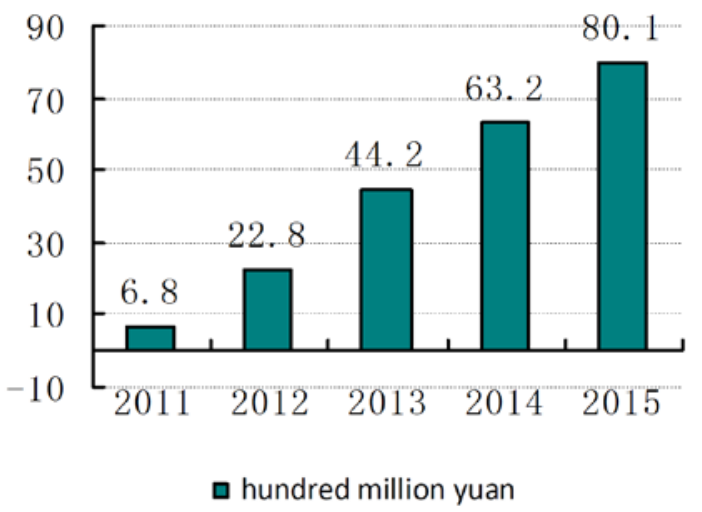

Figure 1. State Grid charging facilities investment planning

\subsection{Domestic charging station policy introduced delay, the policy risks still remain}

September 2013, the new energy vehicle charging station construction subsidy policies introduced; June 2014, the National Energy Board started to develop the "electric vehicle charging infrastructure planning" and "charging infrastructure guidance" from the construction, operation, management, strengthen the construction of multi-level depth charging stations support; September 22, 2015, the 
Ministry issued the "electric vehicle conductive charging connections apparatus" to solve the new energy vehicle interface confusion; At the end of 2015, AQSIQ, the State Standards Committee Joint National Energy Board, the Ministry of Industry, Science and Technology and other departments issued a electric vehicle charging interfaces and communications protocols 5 national standards, the new standards from January 1, 2016 implementation.

In summary, the government began revised charging station policy from 2013, in 2014 developed charging station construction plan, showing the lack of national attention and late charge station construction. By the end of 2015, the market has emerged in charge stations interface is not unified, charging stations poor compatibility brutal current situation, in the various sectors in the long-awaited, charging station five standard policies finally introduced, we can see the charging stations resolve implementation issues, corresponding policies without delay.

\subsection{Domestic charging station research companies started late, the technology is relatively backward}

Table 2. 11 charge station companies annual report in 2014 (unit in millions)

\begin{tabular}{|c|c|c|c|c|}
\hline Companies & $\begin{array}{l}\text { Operating } \\
\text { income }\end{array}$ & Net profit & YOY & Business Development Overview \\
\hline XJ Electric & 8359 & 1062 & $45.74 \%$ & $\begin{array}{l}\text { Beijing-Shanghai, Beijing-Hong Kong-Macao } \\
\text { Expressway charging stations have been successfully } \\
\text { put into use. Other provinces charge for power plants } \\
\text { and other projects are being carried out smoothly. }\end{array}$ \\
\hline $\begin{array}{l}\text { Shanghai } \\
\text { Putian }\end{array}$ & 1787 & 9.12 & $-41.42 \%$ & $\begin{array}{l}\text { One of the main suppliers of Guangdong, with a } \\
\text { complete solution for charging equipment R \& D and } \\
\text { manufacturing. }\end{array}$ \\
\hline BDP & 939 & $9^{45.6}$ & $46.48 \%$ & $\begin{array}{l}\text { Integrated energy business is focused on the future } \\
\text { direction of development. }\end{array}$ \\
\hline NARI & 8907 & 1283 & $-19.82 \%$ & $\begin{array}{l}\text { It has a larger market space in the electric vehicle } \\
\text { charging for electric service. }\end{array}$ \\
\hline $\begin{array}{l}\text { Zhongheng } \\
\text { Electric }\end{array}$ & 600 & 126 & $41.33 \%$ & $\begin{array}{l}\text { Develop ZHC series of electric vehicle charging } \\
\text { equipment products. }\end{array}$ \\
\hline SAC & 4861 & -341 & & $\begin{array}{l}\text { The total package of new energy business orders } \\
\text { declined than last year. }\end{array}$ \\
\hline $\begin{array}{l}\text { Heshun } \\
\text { Electric }\end{array}$ & 325 & $\begin{array}{l}5195 \\
8\end{array}$ & $-17.10 \%$ & $\begin{array}{l}\text { It has been developed to meet different specifications, } \\
\text { power, charging occasions demand a series of new } \\
\text { energy vehicles charging for electric products. }\end{array}$ \\
\hline Kazuma & 5847 & 235 & $6.99 \%$ & $\begin{array}{l}\text { It successfully completed the country's first scenery } \\
\text { storage integration of intelligent transport reform } \\
\text { energy vehicle charging stations. }\end{array}$ \\
\hline $\begin{array}{l}\text { Siyuan } \\
\text { Electric }\end{array}$ & 3670 & 456 & $31.59 \%$ & $\begin{array}{l}\text { Existing products in the State Grid and China Southern } \\
\text { Power Grid and so further enhance the market share. }\end{array}$ \\
\hline Kstar & 1388 & 153 & $20.43 \%$ & $\begin{array}{l}\text { It is in accordance with national standards developed } \\
\text { DC charging stations, AC charging and other products. }\end{array}$ \\
\hline INVT & 1058 & 162 & $31.12 \%$ & $\begin{array}{l}\text { It has successfully developed a new energy electric } \\
\text { car-related product. }\end{array}$ \\
\hline
\end{tabular}


According to the survey, there are about 200 start-up companies are developing business charging stations, charging stations in the domestic industry occupy a major share of the following 11 companies, Table 2 is 11 charge station company's annual report in 2014(unit in million).

As can be seen from Table 2 that the charge station companies business profile, they made a great effort on the development of every company in charge station, but R \& D results compared with foreign big gap. The United States has adopted wireless charging technology, Japan's Fast Charge Technology ranked first in the world, France will be fully integrated into the Internet system, and China in these areas is still in infancy. Thus, charging stations accelerate technology development imperative, how can the charge stations better service customers, promote the development of charging stations is the key step on the way forward energy saving in China.

\section{Problems analysis of charging stations}

Application of large-scale construction of charging facilities lag is caused by a variety aspects. Internal factors policies, business investment and technical reserves have contributed to the promotion is not enough, low public acceptance.

\subsection{Cause analysis of policy}

(1) Inadequate funding subsidies. Although the government implements a capital subsidy policy to charging facilities construction companies, but there are many loopholes in the policy. Many companies in order to obtain subsidies to construct charging facilities, and not responsible for maintaining quality and after construction.

(2) Planning enforcement is poor. The introduction of performance standards and subsidies are only the first step in the development of charging stations. In actual operation, there are many policy implemented not thoroughly and understand the provisions of the deviation of the case.

(3) Charging station construction land problem significantly. Although the government has issued charging stations guidance to promote the construction, but did not put the appropriate charge station construction land acquisition and land use planning.

(4) Government charge station construction funds invested can not enough to match with the rapid growth of new energy vehicle sales. The government propagandist strength is not enough for new energy vehicles, which caused a lot of obstacles to private charge station construction.

\subsection{Cause analysis of charging companies}

(1) Companies are not enthusiastic to the charge stations. Nowadays since the charge station construction has been at a loss, does not give business revenue, seriously affected the enthusiasm of companies to build charging stations.

(2) It failed to launch a successful business model. Due to operating public charging stations prices are not introduced, the charging stations are "experiential operational" stage, power grid construction stations and charging stations no profits, loss of operation, resulting in the original highly optimistic about the charge station industry.

(3) Operational management issues. Many charge station construction due to the inappropriate siting, operation and management resulting in the charge stations caused some difficulties. Secondly, the service of charge station construction were not taken seriously, there were no staff timely maintenance when many charging stations after a failure.

\subsection{Analysis of technical reasons}

(1) Existing charging station technique in use, there are still some problems, such as slow charging speed, long charging time, can no longer meet the needs of owners of new energy vehicles. At present, 
charge stations in the planning and construction, the majority of planning in commercial shopping centres, transport hubs areas, need to pay high parking fees, increase the cost of charging.

(2) The domestic charge station construction can provide only charging functionality, and other value-added services do not realize, for example, the use of online booking, online payment.

(3) Charging stations have been installed in a large part of the state of damage, which fully describe the quality of charging stations to be further improved, both from external charging poles and internal charging circuit are to be strengthened, to reduce waste of resources.

\section{Countermeasures and suggestions on charging stations large scale}

\subsection{Improve management policies and encourage multi-funding invest charge stations}

(1) Formulate and improve relevant policies, ensure the policies issued timeliness and effectiveness. Government improve processing efficiency, simplify charging station planning and construction approval process, establish a special fund for the charging infrastructure, finance give some financial support.

(2) Increase investment, encourage multi-party capital investment and construction. Encourage the introduction of foreign investment in construction, while learning international advanced technology, business model and internal management.

(3) Safeguard charging facilities land area, coordination of land conflicts. The independent charging station utilities site in the area of outlets scope of land, simplify the land use rights to approval procedures and formalities.

(4) Strengthen local supervision, maintenance and implementation of the policies into effect. According to relevant national policies, giving local charge station construction related to appropriate financial support.

\subsection{Promote supporting policies and accelerate the public charging infrastructure}

(1)Speed up the public charging infrastructure. Solve the charging infrastructure siting, transform the building's parking with charging function.

(2) Combined charge station construction, deepening reform to promote the sale of electricity side. Encouraged the sale of electricity distribution companies new investment in the construction of charging stations, to promote the sale of electricity side of the deepening of reform.

(3) Develop a reasonable charge stations use policies to avoid duplicate charges. Formulate charging stations use fees and tax benefits, take parking and other factors into account.

(4) Perfect charging station derivative products, improve service quality. Collect accurate information charging stations, combined with the Internet, GPRS and other technologies for real-time updates.

\subsection{Adhere to institutional innovation, optimize the integration of charging station industrial chain}

(1)Integrated charging station industrial chain, explore new economic development model. Integrated grid companies, power companies on sale, new energy vehicles companies, charging station companies, exchange and learn from existing business model, combined with China's development characteristics, forming linkage mechanism to promote the development of industry as a whole.

(2) Set up mixed ownership, stimulate the vitality and creativity of economies. Regard national corporation as the center, develop private companies and foreign-funded companies to make the formation of mixed ownership; explore non-public capital holding mainly state-owned shares of the capital charge station businesses to form a new model of commercial operations. 
(3) Strengthen cooperation, forming a virtuous circle of cooperation and win-win. Each department strengthen the information communication industry chain, to form a charge station anchored in the new energy vehicle charging grid for ease of use for the purpose of promoting common development through cooperation.

\subsection{Accelerating technological innovation, research and development of multi-type charging station substantial market}

(1) Increase investment in research, promoting quality and sales. Companies make good use of subsidies, research and development of wireless charging, fast charging with the new technologies, improve their competitiveness, dominate the market in the competition.

(2) To achieve charging electronic components technological innovation and enhance the overall quality of the charge stations, extend the life of the charging stations.

(3) Solve the charging station using security issues. Charging station research and development companies should continue to improve the technology about safety and reliability.

\subsection{Resolve outstanding issues, coordinating the charging station construction and living contradiction}

(1) Focused on solving the residence and charge station construction contradiction. Initiate the community charge station property management and grid coordinated approach to promote policy reform, installed for accurate layout, orientation coordinate and special resolve.

(2) Reasonable construction of public land, large parking facilities and other places. Gradually rebuilt and open to some companies and institutions dedicated charging facilities to enhance the utilization, according to population density, area and other elements of reasonable arrange for charging station density and frequency of use.

(3) Coordination user self charging station problems and open issues. Perfect underground parking garage with power lines, encourage the building of its own charging station, encourage the establishment of time-sharing mechanism.

\subsection{Improve the quality of service, using the Internet plus make charging stations facilitation}

(1) Using "Internet plus" to solve the charging station uses. Based on the "Internet plus" developing value-added services, such as APP payments, charging station appointments.

(2) Increase companies based on the appropriate "compatible" of charging station service. Strengthen the charging stations operation completed maintenance, updated charging station information in real time, achieve a car with a charging pile, expand charging platform information coverage.

\section{Conclusion}

In the future, the wider use of new energy vehicles is a trend, through the use of new energy sources significantly reduce vehicle exhaust emissions, not only can save part of the non-renewable energy use, and reduce environmental pollution, achieving "green travel to promote sustained and healthy economic development. The author analyzes the current situation in-depth study of the charging pile, problems, key issues affecting factors, countermeasures and economic benefits, the introduction of specific policy recommendations to the relevant government departments to provide scientific, reliable theoretical basis, but also for the government, many cooperative enterprises and the masses have pointed out the direction of the aspects of cooperation. 


\section{References}

1. Guo, F.,Inoa, E.,Choi, W.,Wang, J.Study on Global Optimization and Control Strategy Development for a PHEV Charging Facility. Vehicular Technology, IEEE Transactions on. 2012:1012-1019.

2. Kuperman A,Levy U,Goren J, et al. Battery Charger for Electric Vehicle Traction Battery Switch Station. IEEE Transactions on Industrial Electronics. 2013:77-85.

3. Yang Bing, Wang Lifang, Liao Chenglin. Large-scale electric vehicle charging needs and influencing factors [J]. Electrical Technology. (02):44-50(2013).

4. Yao Weifeng, Zhao Junhua, Wen Fushuan, Xue Yusheng, Dong Chaoyang. Coordinated planning and distribution systems of electric vehicle charging network [J]. Automation of Electric Power Systems, 09:10-18(2015).

5. Battery charging station and promote new energy vehicle market booming [J]. Power Technologies, 07:1344(2015). 